\title{
Influence of biflorin on the labelling of red blood cells, plasma protein, cell protein, and lymphocytes with technetium-99m: in vitro study
}

\author{
Thiago M. Aquino1, Elba L. C. Amorim¹, Gláucio Diré Feliciano ${ }^{2}$, Elaine A. C. Lima², Maria \\ L. Gomes ${ }^{2}$, Cláudia S. A. Lima ${ }^{3}$, Ulysses P. Albuquerque ${ }^{4}$, Mário Bernardo-Filho $^{2 *}$
}

${ }^{1}$ Universidade Federal de Pernambuco, Departamento de Ciências Farmacêuticas, Av. Professor Artur de Sá, S/N, 50521-741, Recife, PE, Brazil,

${ }^{2}$ Universidade do Estado do Rio de Janeiro, Departamento de Biofísica e Biometria, Av. 28 de Setembro, 20551-030, Rio de Janeiro, RJ, Brazil,

${ }^{3}$ Universidade Federal de Pernambuco, Departamento de Biofísica e Radiobiologia, Av. Professor Moraes Rego, 1235, 50670-901, Recife, PE, Brazil, ${ }^{4}$ Universidade Federal Rural de Pernambuco, Departamento de Biologia, Rua Dom Manoel de Medeiros, S/N, 52171-900, Recife, PE, Brazil

\begin{abstract}
RESUMO: "Influência da biflorina na marcação do tecnécio-99m em células vermelhas do sangue, proteínas do plasma, proteínas celulares e em linfócitos: estudos in vitro”. Neste artigo relatam-se os resultados de um estudo in vitro envolvendo a influência da biflorina (uma o-quinona isolada de Capraria biflora L. que possui uma potente atividade antimicrobiana) na marcação do Tc-99m em células vermelhas do sangue, proteínas do plasma, proteínas celulares e em linfócitos. O sangue foi coletado de ratos Wistar e incubado com várias concentrações de biflorina, e soluções de cloreto estanoso $\left(\mathrm{SnCl}_{2}\right)$ adicionando-se Tc-99m. O plasma $(\mathrm{P})$ e as células vermelhas do sangue (CVS) foram isolados, precipitados e centrifugados, isolando-se as frações solúveis (FS) e insolúveis (FI). A maior concentração de biflorina (100\%) é capaz de reduzir a captação do Tc-99m (\%ATI) nas CVS e a fixação na FI-P. Uma solução de 0,2 mL de linfócitos (2,5 mL; 1.0 x $10^{6}$ células $\left./ \mathrm{mL}\right)$, obtidos por centrifugação de sangue humano tratado com Ficoll-Hypac, foi incubada com biflorina (0,1 mL). Soluções de cloreto estanoso e Tc-99m foram então adicionadas. Os linfócitos foram separados e o \%ATI presente nessas células foi avaliado. Uma redução no \%ATI (de 97,85 \pm 0,99 a $88,86 \pm 5$ ) foi observada para CVS e para FI-P (73,24 $\pm 5,51$ a 20,72 $\pm 6,95)$. Os resultados não mostraram decréscimo no \%ATI para os linfócitos com biflorina.
\end{abstract}

Unitermos: Capraria biflora, radiofarmacêuticos, pertecnetato de sódio.

\begin{abstract}
In this paper we report the results of an in vitro study involving the influence of biflorin (an o-quinone isolated from Capraria biflora L. that has potent antimicrobial activity) on the Tc-99m labeling of red blood cells, plasma protein, cells protein, and lymphocytes. Blood was withdrawn from Wistar rats and incubated with various concentrations of biflorin, and solutions of stannous chloride and Tc-99m were added. Plasma (P) and red blood cells (RBC) were isolated, precipitated, and centrifuged, and soluble (SF) and insoluble (IF) fractions were isolated. The results show that the highest concentration (100\%) of biflorin is able to reduce the uptake of Tc-99m (\%ATI) on RBC and the fixation on IF-P. To study the influence of biflorin on 99mTc lymphocyte labeling, human blood was submitted to a technique with Ficoll-Hypac and centrifuged, and white cells were isolated. Lymphocytes $\left(2.5 \mathrm{~mL} ; 1.0 \times 10^{6}\right.$ cells $\left./ \mathrm{mL}\right)$ were obtained and a $0.2 \mathrm{~mL}$ solution was incubated with biflorin $(0.1 \mathrm{~mL})$. Solutions of stannous chloride and $99 \mathrm{mTc}$ were added. Lymphocytes were separated and the \%ATI bound in these cells was evaluated. A reduction in \%ATI (from $97.85 \pm 0.99$ to $88.86 \pm 5$ ) was observed for RBC and for IF-P (73.24 \pm 5.51 to $20.72 \pm$ 6.95). In this case the results showed no decrease in \%ATI for the lymphocytes with biflorin.
\end{abstract}

Keywords: Capraria biflora, radiopharmaceuticals, sodium pertecnetate.

\section{INTRODUCTION}

Capraria biflora L. is a species that belongs to the Schrophulariaceae family, and is originally from the Antilles and South America. In Brazil, it is distributed among the states of Minas Gerais and Goiás, and in the coastal area between the states of Piauí and Espírito Santo (Menezes, 1949). In this region, it is known as "chá-daterra”, “chá-do-méxico”, “chá-da-martinica”, “chá-dorio”, “chá-da-américa”, “chá-das-antilhas”, and “chá-de- 
lima” (Comerford, 1996). Biflorin can be isolated from roots of C. biflora L., a substance with an o-quinone structure, which has antibiotic activity against Grampositive bacteria, yeasts, and fungi (Figure 1) (Lima et al., 1958, 1962; Lima; D’Albuquerque, 1958).

We have evaluated the influence of biflorin on the in vitro Tc-99m labeling of red blood cells, plasma protein, cell protein, and lymphocytes. Radiopharmaceuticals are molecules or cells that contain a radioactive atom in their structure and can be used in human beings for the diagnosis or treatment of some diseases (Saha, 1998). The interactions between radiopharmaceuticals and other drugs is an important factor that has received a lot of attention from researchers - these interactions can change the chemical nature of the radiotracer and the biochemical medium of the target, or can interfere in the radiotracer's binding to plasma proteins and/or blood cells (Hladik III; Saha, 1987; Srivastava; Straub, 1990; Sampson, 1996). This may result in the radiopharmaceutical's incorrect biodistribution, leading to imprecise diagnosis, repetitive exams, and patients' unnecessary exposure to radiation (Hladik III; Saha, 1987; Hicks; Arkles, 1992; Kelly et al., 1992; BernardoFilho et al., 1994; Santos et al., 1995; Eising; Reiners, 1998).

\section{MATERIAL AND METHODS}

\section{Biflorin obtention}

A hydroalcoholic extract of the roots of Capraria biflora L. was concentrated at low pressure and submitted to a chromatographic column using $\mathrm{SiO}_{2}(230-$ 400 mesh) as support and a mixture of toluene/AcOEt (8:2); biflorin was yielded in the form of violet crystals.

\section{Preparation of the solutions}

A stock solution was prepared dissolving 25 mg of biflorin in $10 \mathrm{~mL}$ of a $0.9 \% \mathrm{NaCl}$ solution; after centrifugation this was considered as $100 \%$ (2.5 mg/ $\mathrm{mL}$ ). Subsequent to successive dilutions, the following solutions were prepared: $50 \%$ (1.25 mg/mL), 25\% (0.625 $\mathrm{mg} / \mathrm{mL}), 12.5 \%(0.3125 \mathrm{mg} / \mathrm{mL})$ and $6.25 \%(0.1562 \mathrm{mg} /$ $\mathrm{mL})$.

\section{Animals}

Wistar rats (200-250 g) of both sexes were used, obtained from the Universidade do Estado do Rio de Janeiro. The animals were maintained under constant environmental conditions $\left(22 \pm 5{ }^{\circ} \mathrm{C}, 12 \mathrm{~h}\right.$ of light/dark cycle).

\section{Lymphocyte obtention}

Samples of human blood were treated with
Ficoll-Hypac. A lymphocyte solution was obtained $\left(10^{6}\right.$ cells $/ \mathrm{mL}$ ) after centrifugation and treatment with a $0.9 \%$ saline solution.

\section{Study protocol}

The Tc-99m used was obtained from a 99Molibdenium/99mTechnetium generator (Instituto de Pesquisas Energéticas e Nucleares, Comissão Nacional de Energia Nuclear, Brazil). Radioactivity was determined in a gamma well counter (Clinigamma, LKB, Wallac, Finland). The Follow methodology was based in Oliveira et al. (2000) and Santos-Filho; Bernardo-Filho (2005).

Samples $(0.5 \mathrm{~mL})$ of heparinized whole blood (n $=4$ ) from Wistar rats were incubated at room temperature for 60 min with $100 \mu \mathrm{L}$ of biflorin $(6.25,12.5,25,50$, and $100 \%)$. After the incubation period, $0.5 \mathrm{~mL}$ of $\mathrm{SnCl}_{2}$ $(1.2 \mu \mathrm{g} / \mathrm{mL})$ was added as $\mathrm{SnCl}_{2} \cdot 2 \mathrm{H}_{2} \mathrm{O}$ and the incubation continued for another hour. The next step was to add $0.1 \mathrm{~mL}$ of Tc-99m (3.7 MBq) as sodium pertechnetate $\left({ }^{99 \mathrm{~m}} \mathrm{NaTcO}_{4}\right)$, and the incubation continued for another 10 min. These samples were centrifuged and plasma (P) and blood cells (BC) were separated. Aliquots $(20 \mu \mathrm{L})$ of P and $\mathrm{BC}$ were precipitated with $1 \mathrm{~mL}$ of trichloroacetic acid (TCA 5\%), and soluble (SF) and insoluble fractions (IF) were separated. The radioactivity in P, BC, IF-P, SFP, IF-BC, and SF-BC were determined. Subsequently, the percentage of radioactivity (\%ATI) was calculated. A saline solution $(\mathrm{NaCl} 0.9 \%)$ was used for the control experiments.

Samples $(200 \mu \mathrm{L})$ of the lymphocyte solution $(\mathrm{n}=3)$ were incubated with $100 \mu \mathrm{L}$ of biflorin (100\%) during one hour. After the incubation, $0.1 \mathrm{~mL}$ of Tc-99m (3.7 $\mathrm{MBq})$ as sodium pertechnetate $\left({ }^{99 \mathrm{~m}} \mathrm{NaTcO}_{4}\right)$ was added and the incubation continued for another $10 \mathrm{~min}$. In the control experiment, the incubation was undertaken with a saline solution ( $\mathrm{NaCl} 0.9 \%)$. The aqueous solution (S) and the lymphocytes (L) were separated, and the percentage of radioactivity (\% ATI ) was calculated.

A statistical analysis (ANOVA) was used in order to compare the results obtained $(\mathrm{p}<0.05)$.

\section{RESULTS}

Table 1 presents the distribution of radioactivity in plasma and red blood cells from whole blood incubated in vitro with different concentrations of biflorin. The analysis of the results indicates that there is an extremely significant decrease $(\mathrm{p}<0.001)$ in the uptake of $99 \mathrm{mTc}$ in the red blood cells, with the $50 \%$ concentration going from $92.92 \pm 4.50$ to $79.51 \pm 3.15$ and the $100 \%$ concentration reaching $64.06 \pm 1.95$.

Table 2 shows the fixation of radioactivity in soluble and insoluble fractions of the whole blood plasma incubated in vitro with different concentrations of biflorin. The results indicates an extremely significant decrease $(p<0.001)$ in the fixation of $99 \mathrm{mTc}$ for the 
$6.25 \%$ concentration (from $71.68 \pm 1.70$ to $6.30 \pm 2.09$ ), the $25 \%$ concentration (decrease to $46.83 \pm 3.01$ ), the $50 \%$ concentration (34.52 \pm 9.16$)$, and $100 \%$ concentration $(29.51 \pm 7.11)$. There is a very significant decrease ( $p$ $<0.01$ ) for the $12.5 \%$ concentration, which dropped to $49.42 \pm 3.37$

Table 3 shows the distribution of radioactivity in soluble and insoluble fractions of red blood cells incubated in vitro with biflorin. The analysis of the results indicates an extreme decrease $(p<0.001)$ in radioactivity fixation in the insoluble fraction of red blood cells only with the $100 \%$ concentration (from $80.83 \pm 4.82$ to 56.45 $\pm 8.71)$.
Table 4 shows the percentage of radioactivity in lymphocytes from the aqueous solution incubated with biflorin (100\%). The results indicate no decrease on the lymphocyte labeled at the concentrations used.

\section{DISCUSSION}

The in vitro studies indicated that biflorin behaves similarly to commercial drugs such as hydralazine, prazosin, digoxin, and methyldopa, which decrease the efficiency of red blood cell labeling with Tc-99m. Other drugs - such as propanolol, chlorothiazide, and furosemide - can also significantly reduce labeling<smiles></smiles>

Figure 1. Chemical structure of biflorin, isolated from the roots of Capraria biflora L.

Table 1. Influence of biflorin on the labeling of red blood cells and plasma with Tc-99m.

\begin{tabular}{c|c|c}
\hline \multirow{2}{*}{$\begin{array}{c}\text { Biflorin concentrations } \\
(\%)\end{array}$} & BC & \%ATI \\
\cline { 2 - 3 } 0.0 (control) & $92.92 \pm 4.50$ & $7.06 \pm 4.50$ \\
6.25 & $97.07 \pm 1.16^{\mathrm{ns}}$ & $2.92 \pm 1.16$ \\
12.5 & $96.70 \pm 0.64^{\mathrm{ns}}$ & $3.28 \pm 0.64$ \\
25.0 & $92.14 \pm 1.53^{\mathrm{ns}}$ & $7.85 \pm 1.53$ \\
50.0 & $79.51 \pm 3.15^{* * *}$ & $20.48 \pm 3.15$ \\
100.0 & $64.06 \pm 1.95^{* * *}$ & $35.92 \pm 1.95$ \\
\hline
\end{tabular}

*** - value of $\mathrm{p}<0.001$ considered extremely significant; ns - not significant; \%ATI - percentage of radioactivity; P - plasma; BC - blood cells.

Table 2. Effect of biflorin on the labeling of insoluble fractions of plasma with Tc-99m.

\begin{tabular}{c|c|c}
\hline \multirow{2}{*}{$\begin{array}{c}\text { Biflorin concentrations } \\
(\%)\end{array}$} & IF-P & \%ATI \\
\cline { 2 - 3 } & $71.68 \pm 1.70$ & $28.30 \pm 1.70$ \\
6.0 (control) & $6.30 \pm 2.09^{* * *}$ & $93.68 \pm 2.09$ \\
12.5 & $49.42 \pm 3.37 * *$ & $50.57 \pm 3.37$ \\
25.0 & $46.83 \pm 3.01 * * *$ & $53.15 \pm 3.01$ \\
50.0 & $34.52 \pm 9.16^{* * *}$ & $65.46 \pm 9.16$ \\
100.0 & $29.51 \pm 7.11^{* * *}$ & $70.47 \pm 7.11$ \\
\hline
\end{tabular}

** - value of $\mathrm{p}<0.01$ considered very significant; *** - value of $\mathrm{p}<0.001$ considered extremely significant; \%ATI - percentage of radioactivity; SF-P - soluble fraction of plasma; IF-P - insoluble fraction of plasma. 
Table 3. Influence of biflorin on the labeling of insoluble fractions of red blood cells with Tc-99m.

\begin{tabular}{l|c|c}
\hline \multirow{2}{*}{$\begin{array}{c}\text { Biflorin concentrations } \\
(\%)\end{array}$} & IF-BC & \%ATI \\
\cline { 2 - 3 } & \multicolumn{2}{|c}{ SF-BC } \\
\hline .0 (control) & $80.83 \pm 4.82$ & $19.15 \pm 4.82$ \\
12.5 & $88.70 \pm 3.76^{\text {ns }}$ & $11.28 \pm 3.76$ \\
25.0 & $79.38 \pm 1.60^{\text {ns }}$ & $20.60 \pm 1.60$ \\
50.0 & $81.17 \pm 2.47^{\text {ns }}$ & $18.81 \pm 2.47$ \\
100.0 & $77.75 \pm 2.68^{\text {ns }}$ & $22.23 \pm 2.67$ \\
\hline
\end{tabular}

Value of $\mathrm{p}<0.001$ considered extremely significant; ns - not significant; \%ATI - percentage of the radioactivity; SF-C - soluble fraction of the blood cells; IF-C - insoluble fraction of the blood cells.

Table 4. Percentage of radioactivity (\%ATI) of the lymphocytes incubated in vitro with biflorin.

\begin{tabular}{c|c|c}
\hline \multirow{2}{*}{ Fraction } & \multicolumn{2}{|c}{ \%ATI } \\
\cline { 2 - 3 } & Control & Biflorin $(100 \%)$ \\
S & $9.54 \pm 2.18$ & $10.43 \pm 7.47^{\text {ns }}$ \\
L & $90.45 \pm 2.18$ & $89.56 \pm 7.47^{\text {ns }}$ \\
\hline
\end{tabular}

\%ATI - percentage of radioactivity; ns - not significant; S - aqueous solution; L - lymphocytes.

efficiency in clinical doses (Sampson, 1996). In vitro tests have demonstrated that biflorin also decrease the labeling of cellular protein by Tc-99m, which may indicate that it is affecting the permeability of red blood cell membranes.

The processes involved in the passage of $\mathrm{SnCl}_{2}$ and sodium pertechnetate ions into RBCs have not yet been completely revealed, although data suggests that the former passes through the cell membrane by way of selective calcium channels, and the latter by the "band3 anion" transport system (Sampson, 1996; Callahan; Rabito, 1990; Gutfilen et al., 1992; Smith, 1985; Stryer, 1998).

When a drug or plant extract alters the activity percentage (ATI\%) of hemocytes or other blood components, it may be the result of: competition with $\mathrm{SnCl}_{2}$ or sodium pertechnetate for plasma membrane transport mechanisms; morphological modification of the red blood cells at the plasma membrane level, favoring or inhibiting transport through them; competition for other $\mathrm{SnCl}_{2}$, sodium pertechnetate, or radiotracer binding sites; destabilization of the link between Tc-99m and plasma protein, which would alter their distribution within the organism's circulatory system; action as oxidizing or reducing agents and altering the valence of the tin or pertechnetate ions, thus increasing or decreasing the red blood cells' labeling process (Hladik III; Saha, 1987; Santos et al., 1995).

In a general way it was demonstrated that biflorin can alter the binding of radiopharmaceutical Tc-99m to blood components. Thus, the administration of pharmaceutical preparations containing both biflorin and the radiotracer pertechnetate may result in incorrect diagnostic interpretations (Carlsson, 1995).

\section{REFERENCES}

Bernardo-Filho M, Gutfilen B, Maciel OS 1994. Effect of different anticoagulant on the labeling of red blood cells and plasma proteins with Tc-99m. Nucl Med Commun 15: 730-734.

Callahan RJ, Rabito AC 1990. Radiolabeling of erythrocytes with technetium-99m: role of band-3 protein in the transport of pertechnetate across the cell membrane. $J$ Nucl Med 31: 2004-2010.

Carlsson S 1995. A glance at history of nuclear medicine. Acta Oncol 34: 1095-1102.

Comerford SC 1996. Medicinal plants of two mayan healers from San Andrés, Petén, Guatemala. Econ Bot 50: 327-336.

Eising EG, Reiners C 1998. Influences on evaluability of radionuclide ventriculography in chemotherapy patients. Nucl Med Commun 19: 241-250.

Gutfilen B, Boasquevisque EM, Bernardo-Filho M 1992. Calcium channel blockers: interference on red blood cells and plasma proteins labeling with 99mTc. Rev Esp Med Nucl 11: 195-199.

Hicks RJ, Arkles LB 1992. Efficiency of labeling of red blood cells with technetium-99m after dipyridamole infusion for thallium-201 stress testing. Eur J Nucl Med 19: 1050-1053.

Hladik III WB, Saha GB, Study KT 1987. Essentials of Nuclear Medicine Science, Sidney: Willians and Wilkings.

Kelly MJ, Cowie AR, Antonino A, Barton H, Kalff VJ 1992. An Assessment of factors which influence the effectiveness of the modified in vivo technetium. $J$ Nucl Med 33: 2222-2225.

Lima OG, D’Albuquerque IL 1958. Método de extração e purificação da biflorina. Rev Inst Antibiot 1: 7-9.

Lima OG, D’Albuquerque IL, Neto BM, Albuquerque MM 1958. Breve nota sobre a atividade antimicrobiana da biflorina purificada por partição. Rev Inst Antibiot 1: 95-98. 
Lima OG, D’Albuquerque IL, Navarro MCP 1962. Novo método de extração e purificação da biflorina com possibilidade industrial. Rev Inst Antibiot 1: 79-81.

Menezes AI 1949. Flora da Bahia. São Paulo: Nacional.

Oliveira JF, Braga ACS, Ávila ASR, Araújo AC, Cardoso VN, Bezerra RJAC, Bernardo-Filho M 2000. Assessment of the effect of Maytenus ilicifolia (espinheira santa) extract on the labeling of red blood cells and plasma proteins with technetium-99m. J Ethnopharmacol 72: 179-184.

Saha GB 1998. Fundamentals of Nuclear Pharmacy. New York: Springer-Verlag.

Sampson CB 1996. Complications and difficulties in radiolabeling blood cells: a review. Nucl Med Commun 17: 648-658.

Santos JS, Paula EF, Correa TG, Freitas LC, Fonseca LM, Gutfilen B, Bernardo-Filho M 1995. Effect of cyclophosphamide on the bindng of ${ }^{99} \mathrm{TcO}^{-}$and ${ }^{99 m}$ Tc-MDP to blood cells and plasma proteins. Braz J Med Biol Res 28: 131-135.

Santos-Filho SD, Bernardo-Filho M 2005. Efeito de um extrato de hipérico (Hypericum perforatum) na marcação in vitro de elementos sangüíneos com tecnécio-99m e na biodisponibilidade do radiofármaco pertecnetato de sódio em ratos Wistar. Acta Cir Bras 20: 76-80.

Smith EL 1985. Bioquímica dos Mamíferos. Rio de Janeiro: Guanabara Koogan.

Srivastava SC, Straub RF 1990. Blood cell labeling with Tc99m: progress and perspectives. Semin Nucl Med 1: 41-51.

Stryer L 1998. Bioquímica. Rio de Janeiro: Guanabara Koogan. 